\title{
Weathering versus circulation-controlled changes in radiogenic isotope tracer composition of the Labrador Sea and North Atlantic Deep Water
}

\author{
Friedhelm von Blanckenburg and Thomas F. Nägler \\ Isotopengeologie, Mineralogisch-Petrographisches Institut, Universität Bern, Bern, Switzerland
}

\begin{abstract}
Geological reconstructions and general circulation models suggest that the onset of both Northern Hemisphere glaciation, 2.7 Myr ago, and convection of Labrador Sea Water (LSW) were caused by the closure of the Panama Gateway 4.5 Myr ago. Time series data that have been obtained from studies of ferromanganese crusts from the northwestern Atlantic suggest that radiogenic isotopes of intermediate ocean residence time $(\mathrm{Pb}$ and $\mathrm{Nd}$ ) can serve as suitable tracers to reconstruct these events. However, it has been unclear until now as to whether the changes that have been observed in isotope composition at this time are the result of increased thermohaline circulation or due to the effects of increased glacial weathering. In this paper we adopt a box model approach to demonstrate that the shifts in radiogenic isotope compositions are unlikely to be due to changes in convection in LSW but can be explained in terms of increases of erosion levels due to the glaciation of Greenland and Canada. Furthermore, we provide experimental evidence for the incongruent release of a labile fraction of strongly radiogenic $\mathrm{Pb}$ and nonradiogenic $\mathrm{Nd}$ from continental detritus eroding into the Labrador Sea. This can be attributed to the glacial weathering of old continents and accounts for the paradox that one of the areas of the world most deficient in radiogenic $\mathrm{Pb}$ should provide such a rich supply of radiogenic $\mathrm{Pb}$ to the oceans. An important general conclusion is that the compositions of radiogenic isotopes in seawater are not always a reflection of their continental sources. Perhaps more importantly, the transition from chemical weathering to mechanical erosion is likely to result in significant variations in radiogenic tracers in seawater.
\end{abstract}

\section{Introduction}

Isotopic ocean tracers of intermediate residence time (Nd, $\mathrm{Pb}, \mathrm{Hf}$ and $\mathrm{Be}$ ) have been the subject of considerable attention in the past years in studies of long-term (Myr) [Burton et al., 1997; Christensen et al., 1997; Abouchami et al., 1999; Frank et al., 1999; Lee et al., 1999; von Blanckenburg and O'Nions, 1999; Piotrowski et al., 2000] and short-term (the past climate cycles [e.g., Rutberg et al., 2000] changes in ocean circulation and ocean chemistry. The reason for the interest in these tracers lies in the fact that their isotope ratios ${ }^{143} \mathrm{Nd} / 144 \mathrm{Nd}$, $208,207,206 \mathrm{~Pb} /{ }^{204} \mathrm{~Pb},{ }^{176} \mathrm{Hf} /{ }^{177} \mathrm{Hf}$, and ${ }^{10} \mathrm{Be} /{ }^{9} \mathrm{Be}$ are all distinct within different water masses. This is because their short to intermediate residence time limits the scale of homogenization and ensures a distinct signal from the sources of water masses. In particular, North Atlantic Deep Water (NADW) flowing south and Antarctic Bottom Water flowing north in the Atlantic Ocean are, in turn, labeled by distinctive $\mathrm{Nd}, \mathrm{Pb}, \mathrm{Hf}$, and Be isotope ratios [Piepgras and Wasserburg, 1987; Kusakabe et al., 1990; von Blanckenburg et al., 1996; Albarède et al., 1998]. Furthermore, $\mathrm{Nd}$ isotopes allow for the detailed study of the evolution of Labrador Sea Water (LSW) through time as this water mass is characterized by a unique Nd isotope composition due largely to water from Baffin Bay [Stordal and Wasserburg, 1986], which is bordered by ancient continents (Figure 1).

Copyright 2001 by the American Geophysical Union.

Paper number 2000PA000550

0883-8305/01/2000PA000550\$12.00
This observation and the hypothesis that the closure of the Panama Gateway at $4.5 \mathrm{Ma}$ might have been instrumental in initiating the Pleistocene mode of thermohaline circulation by increasing the amount of LSW flowing into NADW by convection [Stanley, 1995; Mikolajewicz and Crowley, 1997; Haug and Tiedemann, 1998] have led to extensive research efforts on isotope records on the Ma time frame. Such records of past isotope compositions in seawater can be reliably and quite easily obtained from the analysis of hydrogenetic ferromanganese crusts. North Atlantic Fe-Mn crusts show a marked decrease in $\varepsilon_{\mathrm{Nd}}$ (where $\varepsilon_{\mathrm{Nd}}$ is the ${ }^{143} \mathrm{Nd} /{ }^{144} \mathrm{Nd}$ ratio normalized to a chondritic value) from -11 to -13 , an increase in ${ }^{206} \mathrm{~Pb} /{ }^{204} \mathrm{~Pb}$ from 18.8 to 19.2 , and a decrease in both ${ }^{207} \mathrm{~Pb} /{ }^{206} \mathrm{~Pb}$ and ${ }^{208} \mathrm{~Pb} /{ }^{206} \mathrm{~Pb}$ over the past $3 \mathrm{Myr}$ [Burton et al., 1997, 1999; Abouchami et al., 1999; Frank et al., 1999; Reynolds et al., 1999] (see also Figure 2). These $\mathrm{Nd}$ and $\mathrm{Pb}$ isotope changes would be compatible with a gradual strengthening of Labrador Sea Water convection. However, similar isotope changes could be accounted for by increased erosion, namely, an increase in the dominance of mechanical erosion versus chemical weathering in Greenland and North America, arising from the Northern Hemisphere glaciation and leading to similar shifts [Burton et al., 1997, 1999; von Blanckenburg and $O^{\prime}$ Nions, 1999]. One of the difficulties inherent in the use of radiogenic tracers in paleoceanography is the fact that both changes in ocean circulation and changes in weathering of the tracer's sources might lead to secular variations in the isotope ratios. Thus it will often not be possible to single out the driving forces that determine isotopic changes [von Blanckenburg, 1999]. 


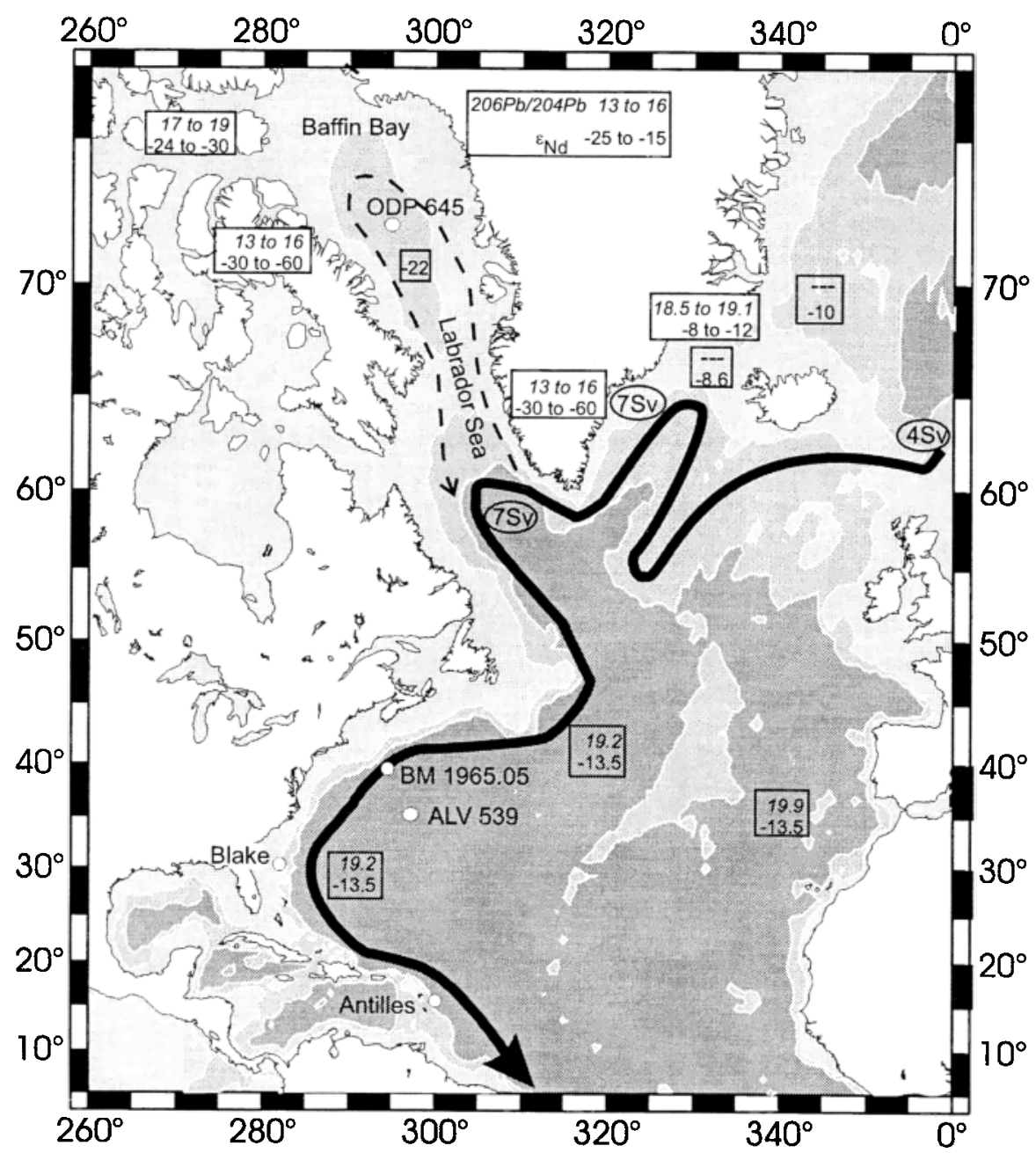

Figure 1. Circulation of deep water in the North Atlantic (solid arrow) and surface circulation through Baffin Bay (dashed arrow). Numbers in ellipses give the amount of deep water formed at these sites in sverdrup $\left(1 \mathrm{~Sv}=1 \times 10^{6} \mathrm{~m}^{3} \mathrm{~s}^{-1}\right)$. A total of $18 \mathrm{~Sv}$ of North Atlantic Deep Water (NADW) are formed by convection in the Greenland-Iceland-Norwegian Seas (11 Sv) and in the Labrador Sea (7 Sv [Schmitz and McCartney, 1993; Dickson and Brown, 1994]. Boxed numbers in italic type are ${ }^{206} \mathrm{~Pb} /{ }^{204} \mathrm{~Pb} \mathrm{ra-}$ tios; other numbers are $\varepsilon_{\mathrm{Nd}}$ of both source rocks [Moorbath et al., 1997; Winter et al., 1997] and $\mathrm{Pb}$ and $\mathrm{Nd}$ dissolved in seawater [Stordal and Wasserburg, 1986; Piepgras and Wasserburg, 1987; von Blanckenburg et al., 1996]. Note that Baffin Bay is surrounded by ancient continents where $\varepsilon_{\mathrm{Nd}}$ is as low as -60 [Moorbath et al., 1997]. In areas surrounding the Greenland-IcelandNorwegian Seas, $\varepsilon_{N d}$ is -20 to -8 (compilation by Winter et al. [1997]. Also shown are the sampling sites of ODP Hole 645 (Baffin Bay) and NW Atlantic Fe-Mn crusts ALV 539, BM 1965.05 [Burton et al., 1997; O'Nions et al., 1998; von Blanckenburg and O'Nions, 1999], Blake, and Antilles [Reynolds et al., 1999].

The aim of this paper is to shed light on the relative importance of weathering effects versus changes in thermohaline circulation for variations in the isotope composition of NADW in the Pleistocene. As a first step we tested the sensitivity with which the isotope composition responds to convection of LSW by utilizing box models of tracer exchange between Baffin Bay and NADW. We will demonstrate that the composition of radiogenic tracers in the North Atlantic responds sensitively to changes in the style of weathering and is insensitive to changes in the strength of thermohaline circulation. To further test the possibility that the causes are changes in the style and degree of weathering, we have performed leaching experiments on the materials that constitute the sources of tracers that erode into the Labrador Sea. These ex- periments simulate the chemical release of tracers due to mechanical erosion of materials, such as those that prevail in strongly glaciated areas.

\section{Experimental Approaches and Results}

\subsection{Tracer Exchange by Changes in the Thermohaline Circulation}

The gradual increase of ${ }^{206} \mathrm{~Pb} /{ }^{204} \mathrm{~Pb}$ from 18.9 to 19.2 and the concomitant decrease of $\varepsilon_{\mathrm{Nd}}$ in the NW Atlantic from -11 to -13 in the past $3 \mathrm{Myr}$ (Figure 2) might be generated by strengthening of LSW convection. This is a possibility discussed frequently in the literature [Burton et al., 1997; Heinze 


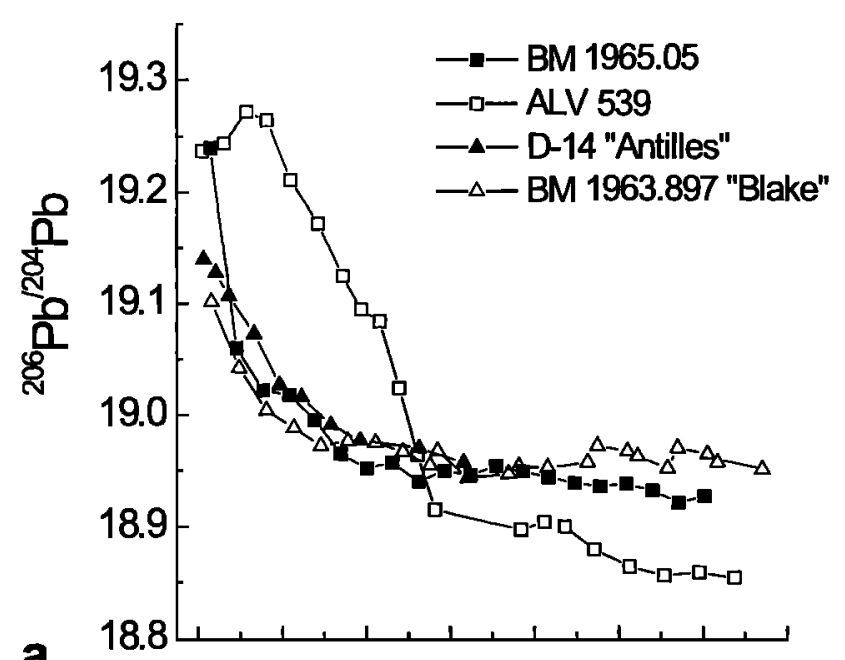

a

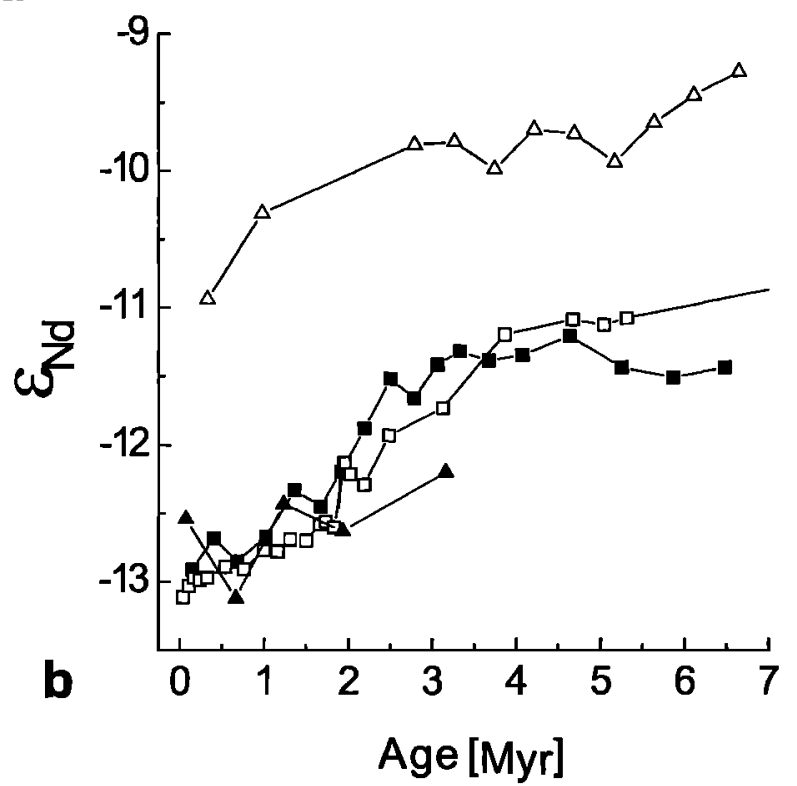

Figure 2. (a) The ${ }^{206} \mathrm{~Pb} /{ }^{204} \mathrm{~Pb}$ isotope ratio variations and (b) $\varepsilon_{\mathrm{Nd}}$ variations in northwest Atlantic Deep Water as recorded by hydrogenetic FeMn crusts [Burton et al., 1999; O'Nions et al., 1998; Reynolds et al., 1999]. These crusts have been dated using the radioactive decay of cosmogenic ${ }^{10} \mathrm{Be}$, which reduces their ${ }^{10} \mathrm{Be} /{ }^{9} \mathrm{Be}$ ratio with time. Note that the major increase in ${ }^{206} \mathrm{~Pb} /{ }^{204} \mathrm{~Pb}$ and decrease in $\varepsilon_{\mathrm{Nd}}$ are after $3 \mathrm{Myr}$, the onset of Northern Hemisphere glaciation, whereas the major hydrographic changes attributed to the closure of the Panama Gateway have taken place at 4.5 Ma [Haug and Tiedemann, 1998].

and Crowley, 1997; Abouchami et al., 1999; Burton et al., 1999; Vance and Burton, 1999]. In order to test this hypothesis the exchange of tracers between Baffin Bay and the entire North Atlantic due to advection was simulated in a simple two-box model (Figure 3). First, an increase of LSW convection was simulated by varying the exchange between Baffin Bay and the North Atlantic between 0 and 10 Sverdrup (1 Sv $=1 \times 10^{6} \mathrm{~m}^{3} \mathrm{~s}^{-1}$ ). Resulting $\varepsilon_{\mathrm{Nd}}$ in the North Atlantic are shown in Figure $3 a$. It is noteworthy that resulting ratios are constant at -10.5 for equal Nd fluxes per unit area into both basins and at -13 for a tenfold increase in Nd flux into Baffin Bay. With the exception of very low exchange rates and a very high Nd flux into Baffin Bay, isotope ratios are virtually independent of the variations in water exchange. This result becomes more obvious when considering the fact that at a present-day exchange rate of $2 \mathrm{~Sv}$ and with the volume given in Figure 3, the contents of Baffin Bay are replenished every 15 years. The Labrador Sea, with a much larger volume, is also replenished over similar timescales because the deep water formation rate is also higher at $7 \mathrm{~Sv}$. In this case the water replenishment rate is much shorter than the tracer's residence time $\tau$, and this tracer's budget in the Atlantic turns out to be insensitive to the rate of water exchange with LSW. Therefore intermediate- $\tau$ tracer advection from one box to the other is essentially limited by the rate at which tracers enter the basin through erosion, regardless of the actual water exchange rate. The only exception to this prediction is if exchange rates are only slightly higher than a total shutoff of LSW convection. In this case the water replenishment time approaches the tracer's residence time, and the North Atlantic's Nd composition becomes sensitive to the water exchange rate with LSW (Figure 3a). The Nd isotope composition of Baffin Bay water resulting from the same experiment (not shown) reacts sensitively to any change in water exchange flux, and the sense of the change is opposite to that in the North Atlantic. Baffin Bay is where changes in deep water generation would show up in the Nd isotope record, whereas in the North Atlantic they would not. However, suitable Fe-Mn crusts have not been recovered from Baffin Bay.

The same simulation has been performed for $\mathrm{Pb}$. Since $\mathrm{Pb}$ has a North Atlantic Deep Water residence time $\tau$ of 40 years [Cochran et al., 1990], which is much closer to the water replenishment time of Baffin Bay or Labrador Sea, Pb isotope variations would be detectable both in the North Atlantic and in Baffin Bay, in particular if the flux of $\mathrm{Pb}$ per unit area into Baffin Bay is much higher than that into the Atlantic (Figure 3b). However, the sense of a shift resulting from strengthening of LSW convection, which is governed by the low $\mathrm{Pb}$ isotope composition of the areas surrounding the Labrador Sea (Figure1), is opposite to that observed in the NW Atlantic Fe-Mn crust records (Figure 2a). Therefore, at first sight, the observed $\mathrm{Pb}$ isotope compositions are also incompatible with a gradual strengthening of LSW convection. The only scenario that is compatible with the observed $\mathrm{Pb}$ isotope trends would be a combination of the strenghtening LSW convection, a high terrigenous $\mathrm{Pb}$ flux into Baffin Bay, and an incongruent release of radiogenic $\mathrm{Pb}$, as explored in section 2.2 .

Baffin Bay Water has a distinctly low Nd isotope composition (Figure 1). Baffin Bay is also the basin with the highest dissolved Nd concentrations of any basins worldwide [Stordal and Wasserburg, 1986]. These observations make a high terrigenous flux of Nd into the basin likely. In Figure $3 \mathrm{c}$ the flux of $\mathrm{Nd}$ into Baffin Bay was increased up to tenfold relative to that of the North Atlantic per unit area while leaving the water exchange rate constant. A strong decrease in North Atlantic $\varepsilon_{\text {Nd }}$ results. An approximately fivefold increase in erosional input would be sufficient to explain the Pleistocene shift in isotope ratios measured in NW Atlantic Fe-Mn crusts. It must be noted, however, that such an increase must be particularly strong in the Labrador Sea area, as a simultaneous increase of Nd released into the other sources of NADW would result in constant isotope compositions. This is not entirely unlikely, 

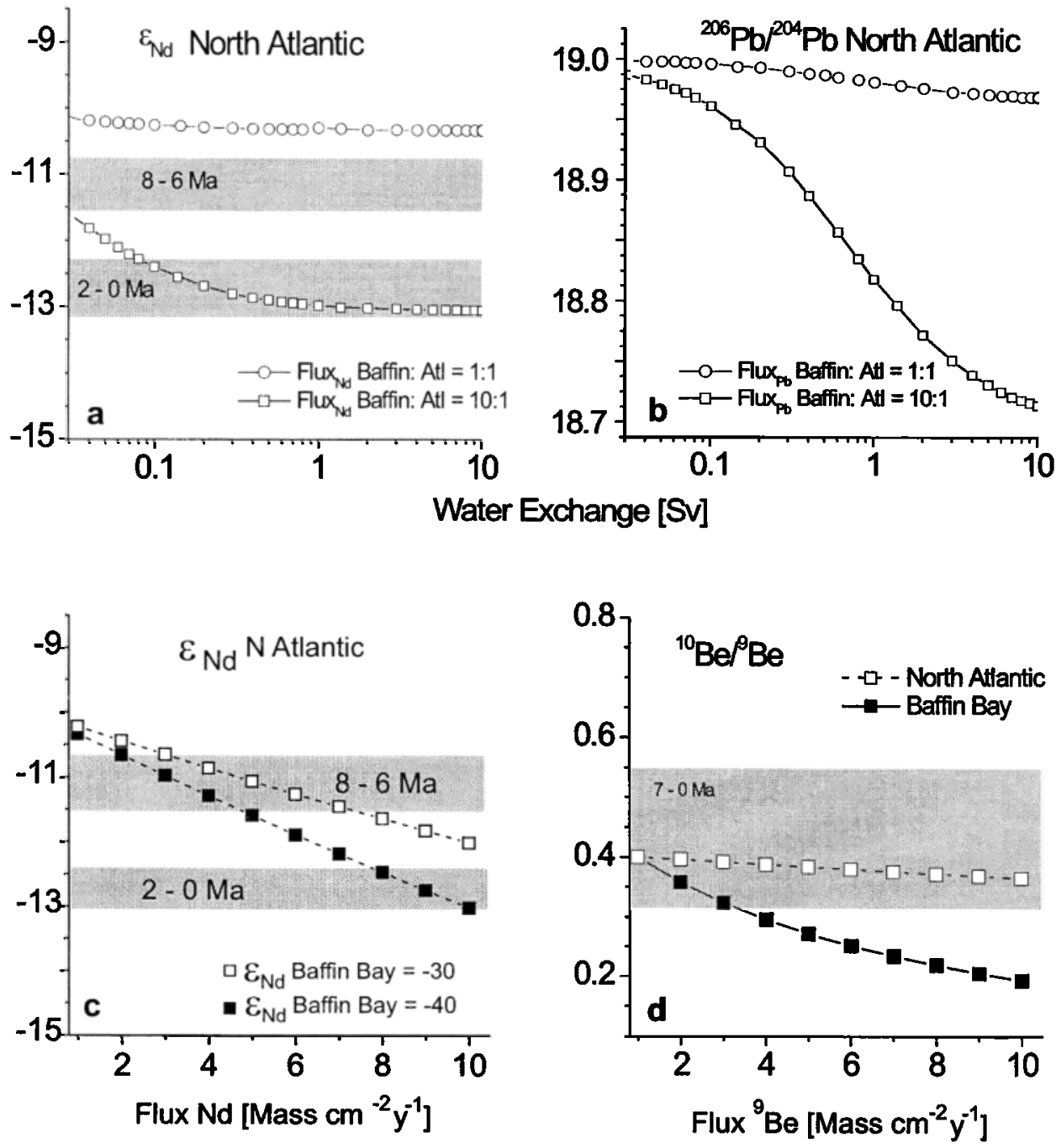

Figure 3. Isotopic ratios calculated from two-box models of tracer exchange between Baffin Bay and the North Atlantic. Results shown are those for the North Atlantic box. The shaded areas are the compositions of NW Atlantic Fe-Mn crusts at different times before and after closure of the Panama Gateway. The Atlantic box has a volume of $1.69 \times 10^{17} \mathrm{~m}^{3}$; Baffin Bay has a volume of $9.6 \times 10^{14} \mathrm{~m}^{3}$. Tracer transport is by advective exchange between Baffin Bay and the North Atlantic. Today this is $\sim 2 \mathrm{~Sv}$ [Schmitz and McCartney, 1993; Dickson and Brown, 1994]. This rate is used for the standard model unless indicated otherwise. Tracers are present for which the removal by scavenging is govemed by their residence time, which is 40 years for $\mathrm{Pb}, 250$ years for $\mathrm{Be}$, and 1000 years for $\mathrm{Nd}$. Erosional tracer flux (total $\mathrm{Pb}, \mathrm{Nd}$ and ${ }^{\mathrm{Be}}$ ) is proportional to the area of the boxes and is 1 mass unit $\mathrm{cm}^{-2} \mathrm{yr}^{-1}$ in the standard model and 10 mass units $\mathrm{cm}^{-2} \mathrm{yr}^{-1}$ into Baffin Bay for the models of Figures $3 a$ and $3 \mathrm{~b}$, shown by squares. Atmospheric ${ }^{10} \mathrm{Be}$ deposition is also uniform over the area and has been held constant at 0.4 mass units $\mathrm{cm}^{-2} \mathrm{yr}^{-1}$, such that an "Atlantic-type" ${ }^{10} \mathrm{Be} /{ }^{\rho} \mathrm{Be}$ ratio of $0.4 \times 10^{-7}$ results. The input of Nd into the North Atlantic box is characterized by an $\varepsilon_{\mathrm{Nd}}$ of -10 , and that into Baffin Bay is characterized by -40 . In Figure $3 \mathrm{c}$ a model is added where the $\varepsilon_{N d}$ of the input to Baffin Bay is -30 [Moorbath et al., 1997; Piepgras and Wasserburg, 1987; Stordal and Wasserburg, 1986]. Input ${ }^{206} \mathrm{~Pb} /{ }^{204} \mathrm{~Pb}$ is 19 in the North Atlantic and 16 in Baffin Bay. It must be noted that the conclusions are not affected by the choices made for the input isotope ratios; it is the relative changes in ratios that matter. ( $a$ and $b$ ) The effect of strengthening of LSW, which was simulated by varying the water exchange rate between Baffin Bay and the North Atlantic between 0 and $10 \mathrm{~Sv}$ for two different $\mathrm{Nd}$ and $\mathrm{Pb}$ fluxes into Baffin Bay. (c) The effect of an increased glacial erosional input into Baffin Bay on North Atlantic Nd chemistry, which was simulated by increasing the flux of $N d$ up to tenfold for two different $\varepsilon_{N d}$ of the input into Baffin Bay. (d) The effect of an increased glacial erosional input into Baffin Bay for the North Atlantic ${ }^{10} \mathrm{Be} /{ }^{9} \mathrm{Be}$ ratio, which was simulated by increasing the flux of ${ }^{9} \mathrm{Be}$ into Baffin Bay up to tenfold while leaving the ${ }^{10} \mathrm{Be}$ flux constant. Runs were also conducted for an exchange between the entire Labrador Sea and the North Atlantic. Because the higher volume of the Labrador Sea is matched by higher water exchange rates, results are very similar to those of the Baffin Bay model.

given the low ratio of the Laboratory Sea's area to the length of its margins, when compared with the other North Atlantic basins.

It has been argued that an increase in erosional flux into the Labrador Sea is an unlikely cause for radiogenic tracer variations, as it would be accompanied by ${ }^{9} \mathrm{Be}$, which would lower the ${ }^{10} \mathrm{Be} /{ }^{9} \mathrm{Be}$ ratio in the same period [Burton et al., 1999]. This is apparently in contradiction to the observation that initial ${ }^{10} \mathrm{Be} /{ }^{9} \mathrm{Be}$ ratios in the NW Atlantic have been constant over the past 7 Myr [von Blanckenburg and O'Nions, 1999]. It can be demonstrated with a fourth model, however, that relative to the entire North Atlantic, the overall increase in the 


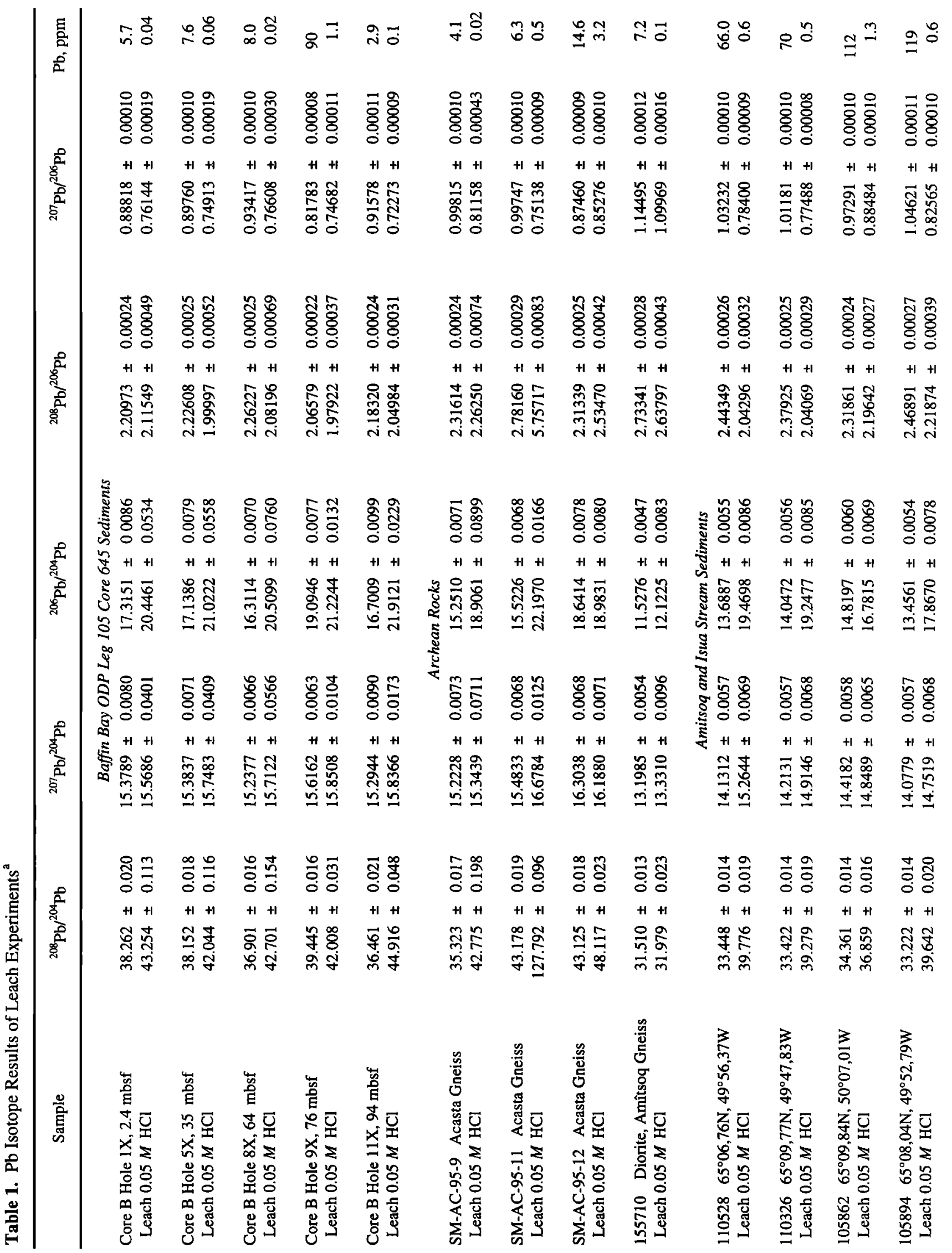




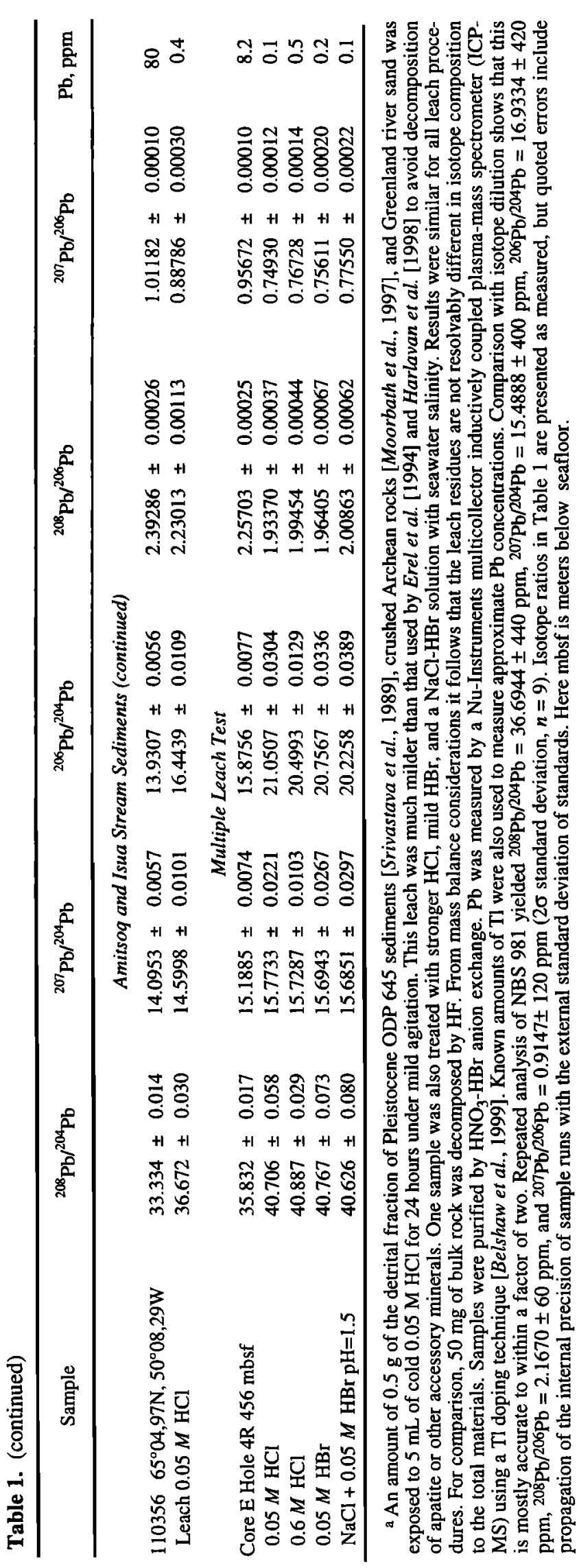

${ }^{9} \mathrm{Be}$ flux associated with an increase in erosion around Baffin Bay is so small that a virtually unresolvable shift in North Atlantic ${ }^{10} \mathrm{Be} /{ }^{9} \mathrm{Be}$ would result (Figure $3 \mathrm{~d}$ ). This is because even a large increase in the flux of ${ }^{9} \mathrm{Be}$ into the Labrador Sea results in only a minute shift in the total ${ }^{9} \mathrm{Be}$ budget in the Atlantic.

\subsection{Tracer Release Experiments}

As noted above, the observed increase in the North Atlantic's radiogenic $\mathrm{Pb}$ over the last $3 \mathrm{Myr}$ is incompatible with either an increase in LSW convection or an overall increase in erosion of the Labrador and Greenland areas. This is because these areas have $\mathrm{a} \mathrm{Pb}$ isotope composition opposite of what would be required to drive this shift (Figure 1). Our explanation for this paradox is that rocks undergoing physical erosion, such as in glaciated areas, will incongruently release a radiogenic fraction of $\mathrm{Pb}$ or $\mathrm{Sr}$ [Erel et al., 1994; Harlavan et al., 1998]. In contrast, soils that have experienced prolonged weathering release tracers having the isotope composition of the bulk soil. Similar observations have been made for Nd: around $70 \%$ of the $\mathrm{Nd}$ is lost from the topsoil of weathered tills, and the residual ${ }^{143} \mathrm{Nd} /{ }^{144} \mathrm{Nd}$ in the soil was higher by up to $4 \varepsilon_{\mathrm{Nd}}$ units than in the unweathered $\mathrm{C}$ horizon [Öhlander $e t$ al., 2000]. In a boreal river, $\varepsilon_{\mathrm{Nd}}$ was lower by almost $10 \varepsilon_{\mathrm{Nd}}$ units than in the unweathered bedrock in the area [Andersson et al., 2001]. This indicates the release of a strongly nonradiogenic Nd fraction into solution from physically eroded materials.

To investigate the tracer release from the weathering of rocks in the areas surrounding the Labrador Sea, Archean rocks, river sediments from Archean Greenland, and the detrital fraction of Pleistocene Ocean Drilling Program sediments from Baffin Bay have been treated using mild acid leaches which have been measured for their $\mathrm{Pb}$ and $\mathrm{Nd}$ isotope composition and compared to the original bulk material (Tables 1 and 2). The analytical details are given in Table 1.

Results (Figure 4) show that in all cases a labile pool of $\mathrm{Pb}$ is available that is much more radiogenic than the bulk rock. For example, a total sediment has a ${ }^{206} \mathrm{~Pb} /{ }^{204} \mathrm{~Pb}$ of 13 , with a leacheate ${ }^{206} \mathrm{~Pb} /{ }^{204} \mathrm{~Pb}$ of 19 . Similar effects are also visible for ${ }^{208} \mathrm{~Pb} / 206 \mathrm{~Pb}$ and ${ }^{207} \mathrm{~Pb} /{ }^{206} \mathrm{~Pb}$. Multiple leach tests further show that this radiogenic fraction is always released, regardless of the reagent used (Table 1). These experiments obviously do not precisely simulate nature in terms of timescale and solution chemistry. However, the simple fact that this labile radiogenic $\mathrm{Pb}$ is available for release in various aqueous solutions makes it very likely that this fraction would be the first to be released into seawater, too. The amount of radiogenic $\mathrm{Pb}$ lost from the deposited sediments is small. Therefore the detrital sediments will, on the whole, retain their original isotope composition, while the overlying water column has a much more radiogenic composition. The sense of these $\mathrm{Pb}$ isotope shifts are exactly the same as those experienced by NADW in the period from $7 \mathrm{Ma}$ to the present (Figure 5). Therefore the variations in NADW $\mathrm{Pb}$ isotope composition are compatible with an increasing amount of mechanically eroded material introduced into Baffin Bay and the Labrador Sea. 
Table 2. Nd Isotope Results of Leach Experiments ${ }^{a}$

\begin{tabular}{|c|c|c|c|c|c|}
\hline Sample & Nd, ppm & $\mathrm{Sm}^{\mathrm{b}}, \mathrm{ppm}$ & ${ }^{147} \mathrm{Sm} /{ }^{144} \mathrm{Nd}$ & ${ }^{143} \mathrm{Nd} /{ }^{144} \mathrm{Nd}$ & $\varepsilon_{\mathrm{Nd}}(0)$ \\
\hline \multicolumn{6}{|c|}{ Baffin Bay ODP Leg 105 Core 645 Sediments } \\
\hline Core B Hole $1 \mathrm{X}, 2.4 \mathrm{mbsf}$ & 6.37 & 1.20 & 0.1135 & $0.511492 \pm 27^{\mathrm{c}}$ & -22.4 \\
\hline Leach $0.05 M \mathrm{HCl}$ & 0.189 & 0.0362 & 0.1161 & $0.511227 \pm 18^{\mathrm{c}}$ & -27.5 \\
\hline Core B Hole 5X, $35 \mathrm{mbsf}$ & 7.72 & 1.32 & 0.1033 & $0.511242 \pm 20^{\circ}$ & -27.2 \\
\hline Leach $0.05 M \mathrm{HCl}$ & 0.200 & 0.004 & 0.1247 & $0.511609 \pm 72^{\circ}$ & -20.1 \\
\hline Core B Hole $8 \mathrm{X}, 64 \mathrm{mbsf}$ & 67.28 & 12.30 & 0.1105 & $0.511141 \pm 20^{\mathrm{a}}$ & -29.2 \\
\hline Leach $0.05 \mathrm{M} \mathrm{HCl}$ & 0.109 & 0.0190 & 0.1054 & $0.511208 \pm 19^{a}$ & -27.9 \\
\hline Core D Hole $14 \mathrm{R}, 400 \mathrm{mbsf}$ & 4.35 & 0.792 & 0.1101 & $0.511446 \pm 27^{\mathrm{c}}$ & -23.3 \\
\hline Leach $005 \mathrm{M} \mathrm{HCl}$ & 0.545 & 0.110 & 0.1217 & $0.511745 \pm 27^{\mathrm{c}}$ & -17.4 \\
\hline Core E Hole 4R, $456 \mathrm{mbsf}$ & 7.27 & 1.32 & 0.1094 & $0.511452 \pm 28^{\mathrm{a}}$ & -23.1 \\
\hline Leach $0.05 M \mathrm{HCl}$ & 1.30 & 0.273 & 0.1272 & $0.511961 \pm 22^{a}$ & -13.2 \\
\hline Core D Hole 9R, 504 mbsf & 7.60 & 1.39 & 0.1107 & $0.511476 \pm 96^{\mathrm{a}}$ & -22.7 \\
\hline Leach $0.05 M \mathrm{HCl}$ & 1.18 & 0.247 & 0.1267 & $0.511607 \pm 25^{\mathrm{a}}$ & -20.1 \\
\hline \multicolumn{6}{|c|}{ Amitsoq and Isua Stream Sediments } \\
\hline $11052865^{\circ} 06,76 \mathrm{~N}, 49^{\circ} 56,37 \mathrm{~W}$ & 54.26 & 11.42 & 0.1272 & $0.510947 \pm 22^{\mathrm{a}}$ & -33.0 \\
\hline Leach $0.05 M \mathrm{HCl}$ & 1.11 & 0.180 & 0.0984 & $0.510358 \pm 31^{\mathrm{a}}$ & -44.5 \\
\hline $1103266^{\circ} 09,77 \mathrm{~N}, 49^{\circ} 47,83 \mathrm{~W}$ & 45.7 & 11.3 & 0.1490 & $0.511397 \pm 26^{\mathrm{a}}$ & -24.2 \\
\hline Leach $0.05 M \mathrm{HCl}$ & 1.14 & 0.215 & 0.1133 & $0.510541 \pm 20^{c}$ & -40.9 \\
\hline $10586265^{\circ} 09,84 \mathrm{~N}, 50^{\circ} 07,01 \mathrm{~W}$ & 82.7 & 15.8 & 0.1151 & $0.5110881 \pm 22^{\alpha}$ & -34.3 \\
\hline Leach $0.05 \mathrm{M} \mathrm{HCl}$ & 3.36 & 0.534 & 0.0959 & $0.510401 \pm 32^{\mathrm{c}}$ & -43.6 \\
\hline $10589465^{\circ} 08,04 \mathrm{~N}, 49^{\circ} 52,79 \mathrm{~W}$ & 39.9 & 8.90 & 0.1347 & $0.511302 \pm 32^{a}$ & -26.1 \\
\hline Leach $0.05 M \mathrm{HCl}$ & 1.53 & 0.223 & 0.0884 & $0.510500 \pm 28^{\mathrm{a}}$ & -41.7 \\
\hline
\end{tabular}

\footnotetext{
a Mass balance calculations show that leach residues (not measured) are all within $0.7 \varepsilon_{\mathrm{Nd}}$ units to those of the corresponding totals.

b Sm concentrations were measured by isotope dilution on MC-ICP-MS.

c Analyses were measured by Thermal Ionization Mass Spectrometry (TIMS) as NdO+ on a modified AVCO single collector instrument $\left({ }^{143} \mathrm{Nd} /{ }^{144} \mathrm{Nd}\right.$ external reproducibility is $0.000034,2 \sigma$ standard deviation, $\left.n=5\right)$. The TIMS results were adjusted by $1 \varepsilon_{\mathrm{Nd}}$ for instrument bias to adjust for a La Jolla value of 0.511860 .

d Samples were measured on a Nu-Instruments multicollector ICP-MS $\left({ }^{143} \mathrm{Nd} /{ }^{144} \mathrm{Nd}\right.$ external reproducibility is $0.000019,2 \sigma$ standard deviation, $n=15$ ). No corrections were required for the Nu ICP-MS data.
}

Fresh Greenland river sediments release a significantly nonradiogenic fraction of Nd (Table 2 and Figure 6). This fraction amounts to $2-3 \%$ of the bulk rock's $\mathrm{Nd}$ and is between 10 and $15 \varepsilon_{\mathrm{Nd}}$ units less radiogenic than the bulk rock. Leacheates of Baffin Bay ODP sediments show smaller differences with respect to their bulk material than those of fresh river sediments, and mostly, the reverse systematics in both $\varepsilon_{\mathrm{Nd}}$ and the $\mathrm{Sm} / \mathrm{Nd}$ ratio are seen (Table 2 and Figure 6). We consider the more radiogenic $\mathrm{Nd}$ fraction measured in the leacheate of ODP sediments to be dominated to a large extent by the fraction that has been adsorbed from seawater. Such Nd would be present in relatively high concentrations in the $\mathrm{Fe}$ Mn oxyhydroxide surface coatings of the minerals [Vance and Burton, 1999] and would reflect the isotope composition of the overlying water column. In surface LSW $2.4 \mathrm{Myr}$ ago $\varepsilon_{\mathrm{Nd}}$ was -13 , and decreased to -18 in LSW and to -22 in Baffin Bay today [Stordal and Wasserburg, 1986; Vance and Burton, 1999]. The increase in ${ }^{147} \mathrm{Sm} /{ }^{144} \mathrm{Nd}$ in the older leacheates is also compatible with a shift from high $\mathrm{Sm} / \mathrm{Nd}$ ratios in seawater $2.4 \mathrm{Myr}$ ago to low ratios observed today [Vance and Burton, 1999]. These shifts in LSW Nd isotope composition and $\mathrm{Sm} / \mathrm{Nd}$ ratio reflect the increased input of labile low $\varepsilon_{\mathrm{Nd}}$ and low Sm/Nd after the onset of Northern Hemisphere glaciation released from mechanically eroded glacial tills.

The question thus arises as to the availability of radiogenic $\mathrm{Pb}$ in ODP sediments, while at the same time, nonradiogenic Nd fraction in the same materials is absent. This contrasts with the behavior of fresh river sediments, which show a greatly incongruent release of both radiogenic $\mathrm{Pb}$ and nonradiogenic Nd. Such differential behavior might be due to 

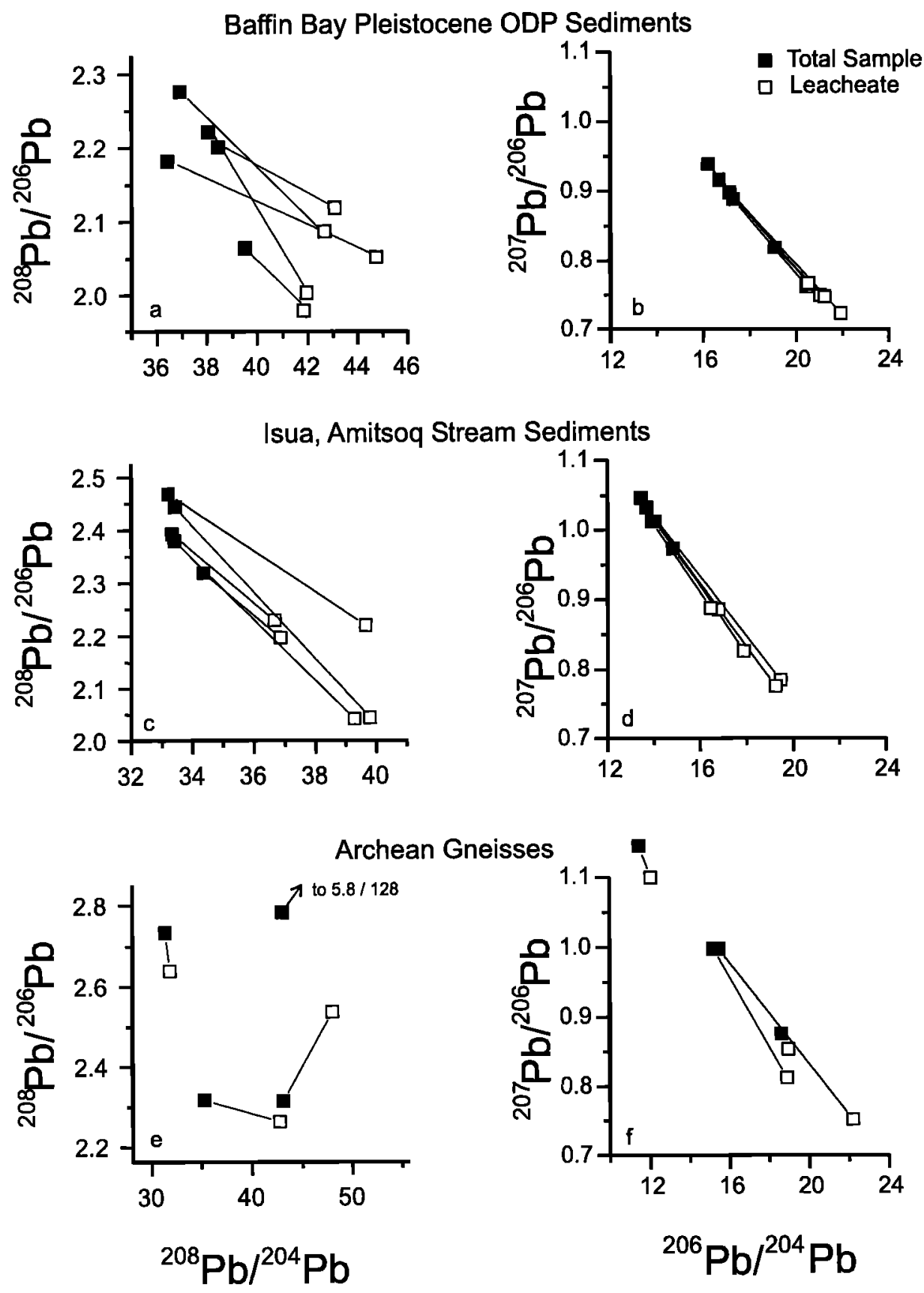

Figure 4. $\mathrm{Pb}$ isotope ratios of dissolved bulk samples (solid squares) and $0.05 \mathrm{M} \mathrm{HCl}$ leacheates (open squares). The latter represent the $\mathrm{Pb}$ available for release into seawater. Analytical detals are given in Table 1. Analytical errors are smaller than symbol sizes.

the fact that the labile nonradiogenic $\mathrm{Nd}$ is immediately lost upon the immersion of the sediment in seawater, whereas a large fraction of the radiogenic $\mathrm{Pb}$ is still available for release. This suggestion is compatible with the large fraction of $\mathrm{Nd}$ (70\%) lost during weathering of glacial tills [Öhlander et al., 2000].

The incongruent release of radiogenic $\mathrm{Pb}$ and of nonradiogenic Nd is typical for a strong mechanical erosion regime where an abundance of fresh mineral surfaces have been opened for weathering. Evidence for weathering of me- chanically eroded materials is provided in soils and clastic sediment by the availability of a labile radiogenic pool of ${ }^{208} \mathrm{~Pb}$ and ${ }^{206} \mathrm{~Pb}$, which is predominantly hosted by accessory minerals (mainly monazite, allanite and xenotime) which might have experienced radiation damage [Erel et al., 1994], or by grain boundaries rich in the parent isotopes ${ }^{238} \mathrm{U}$ and ${ }^{232} \mathrm{Th}$ [Silver et al., 1984]. The low $\varepsilon_{\mathrm{Nd}}$ and the low $\mathrm{Sm} / \mathrm{Nd}$ ratio point to accessory minerals enriched by light rare earth element or grain boundaries as hosts for this labile Nd fraction, too. Upon prolonged chemical weathering this pool is 


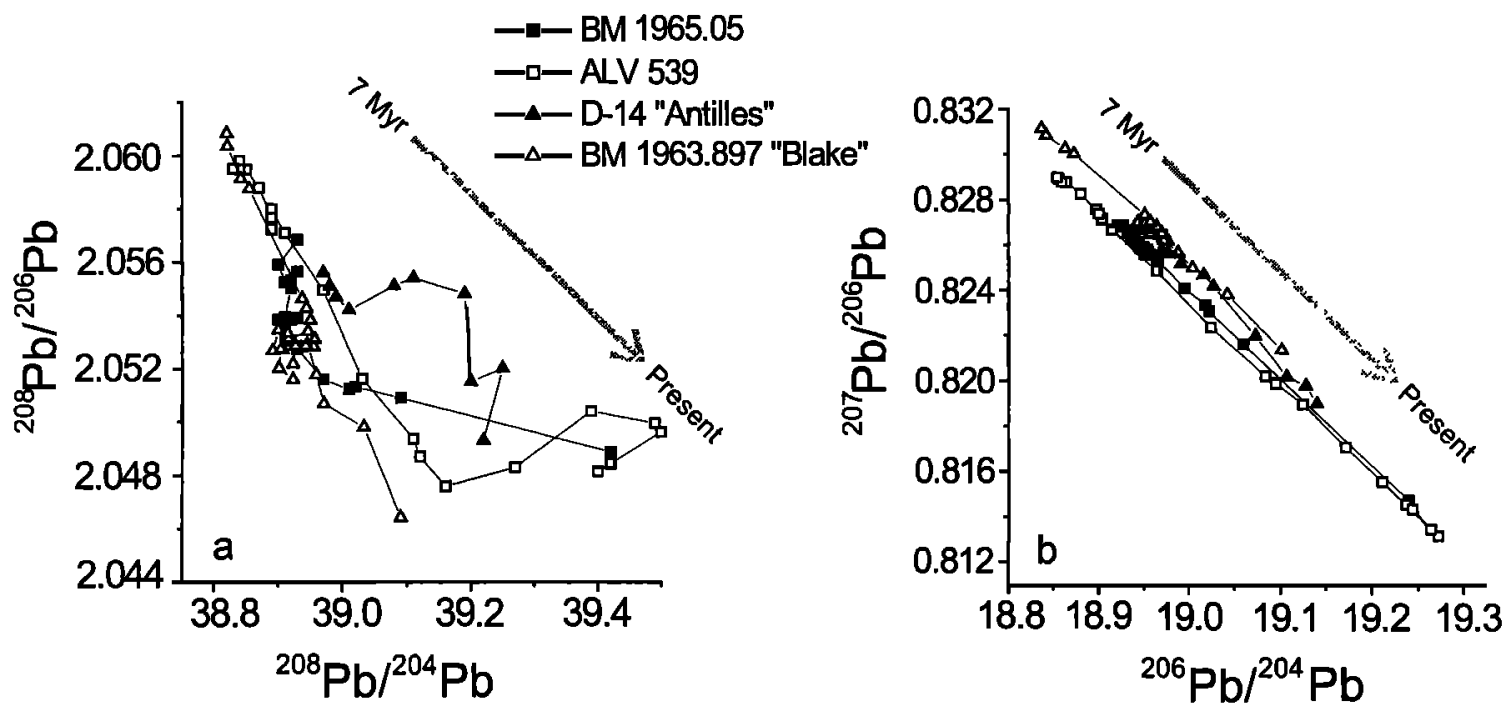

Figure 5. Pb isotope ratio shifts of NADW as recorded in northwest Atlantic Fe-Mn crusts [O'Nions et al., 1998; Burton et al., 1999; Reynolds et al., 1999]. Note that these shifts have the sanie sense as those between bulk rock and leacheates of the experiments shown in Figure 2.

lost into solution [Erel et al., 1994; Harlavan et al., 1998; Öhlander et al., 2000; Andersson et al., 2001]. This mechanism resolves the contradiction that the Labrador Sea provides the most radiogenic seawater $\mathrm{Pb}$ from an area where source rocks are among the least radiogenic in the world (Figure 1). A strong mechanical erosion regime is in operation on the North American and Greenland Shields, where glacial tills are the predominant sources for marine detritus. In support of this the differences in all $\mathrm{Pb}$ and $\mathrm{Nd}$ isotope ratios between the labile fraction and the bulk stream sediment follow the same trend as the early Pleistocene to recent shifts seen in the northwest Atlantic Fe-Mn crusts (Figures 2 and 4). These shifts can thus be attributed to a gradual shift from prolonged chemical weathering to mainly physical erosion during the buildup of the Northern Hemisphere ice sheets. Such incongruent release of isotope tracers would reduce the flux of bulk terrigenous material that otherwise would be required to satisfy the Labrador Sea Water's extreme isotope compositions (section 2.1).

\section{Discussion and Conclusions}

The obvious conclusion is that NADW Nd isotope compositions are insensitive to changes in the LSW contribution. This is in accordance with the suggestion that Nd in LSW itself underwent a major change toward less radiogenic compositions after 2.5 Ma [Vance and Burton, 1999]. Therefore the changes reported in NW Atlantic seawater isotope composition after the onset of Northern Hemisphere glaciation are best interpreted as a consequence of shifts in the style of weathering from chemical to more mechanical (glacial) erosion and also as due to an overall increase in the amount of erosion. Both are related to the formation of ice sheets in Greenland and the Canadian Shield with an increasing supply of icerafted debris [Larsen et al., 1994]. Incongruent weathering of areas surrounding the other sources of NADW, such as the Fennoscandian crust or eastern Greenland, would result in isotope shifts of the same sense as those observed for the Labrador Sea. It has been observed that glacial weathering in the areas surrounding the Arctic seas results in the release of radiogenic $\mathrm{Pb}$, nonradiogenic $\mathrm{Nd}$, and radiogenic $\mathrm{Sr}$ [Winter et al., 1997].

Other radiogenic isotope seawater tracers might be subject to the same mechanism: Hafnium isotopes from the same northwest Atlantic Fe-Mn crusts as those presented in Figure 2 show a shift to less radiogenic values $\left(\varepsilon_{\mathrm{Hf}}\right.$ shifts from +3 to 1 in the past $4 \mathrm{Myr}$ ) that virtually mirrors that of $\mathrm{Nd}$ in the same crusts [Piotrowski et al., 2000]. This is compatible with the exposure of freshly eroded zircon minerals by physical erosion. These are rich in nonradiogenic Hf. Furthermore, the gradual increase in global seawater ${ }^{187} \mathrm{Os} /{ }^{188} \mathrm{Os}$ in the Quaternary was explained by progressive removal of a deeply weathered pre-Quaternary regolith from the Precambrian shields surrounding the Labrador Sea [Peucker-Ehrenbrink and Blum, 1998].

It must be pointed out that some reorganization of smallscale ocean circulation might be visible in the Fe-Mn crust records. For example, the westward shift with time of a local water mass rich in radiogenic $\mathrm{Pb}$ might be responsible for the increase in radiogenic Pb of the Fe-Mn crust ALV 539 (Figures 1 and 2). This shift precedes that experienced by the more westerly crusts by $\sim 1 \mathrm{Ma}$. In a similar way, a time lag between the decrease in $\varepsilon_{\mathrm{Nd}}$ between crust Alv 539 and BM 1965.05 has been explained by vertical shifts of water masses [Burton et al., 1999]. It must be noted, however, that the apparent difference between the $\mathrm{Nd}$ and $\mathrm{Pb}$ isotope time series from ALV 539 and other NW Atlantic crusts has been attributed to a possibly inconsistent chronology [Reynolds et al., 1999]. The overall North Atlantic shifts in $\mathrm{Pb}, \mathrm{Nd}$, and $\mathrm{Hf}$ isotope compositions in the past 3-4 Myr must, however, be caused by changes in erosion rather than lateral reorganization of local circulation: The shifts are visible over large areas, from the east Atlantic [Abouchami et al., 1999] to the Carribean [Reynolds et al., 1999]; they affect tracers of entirely 


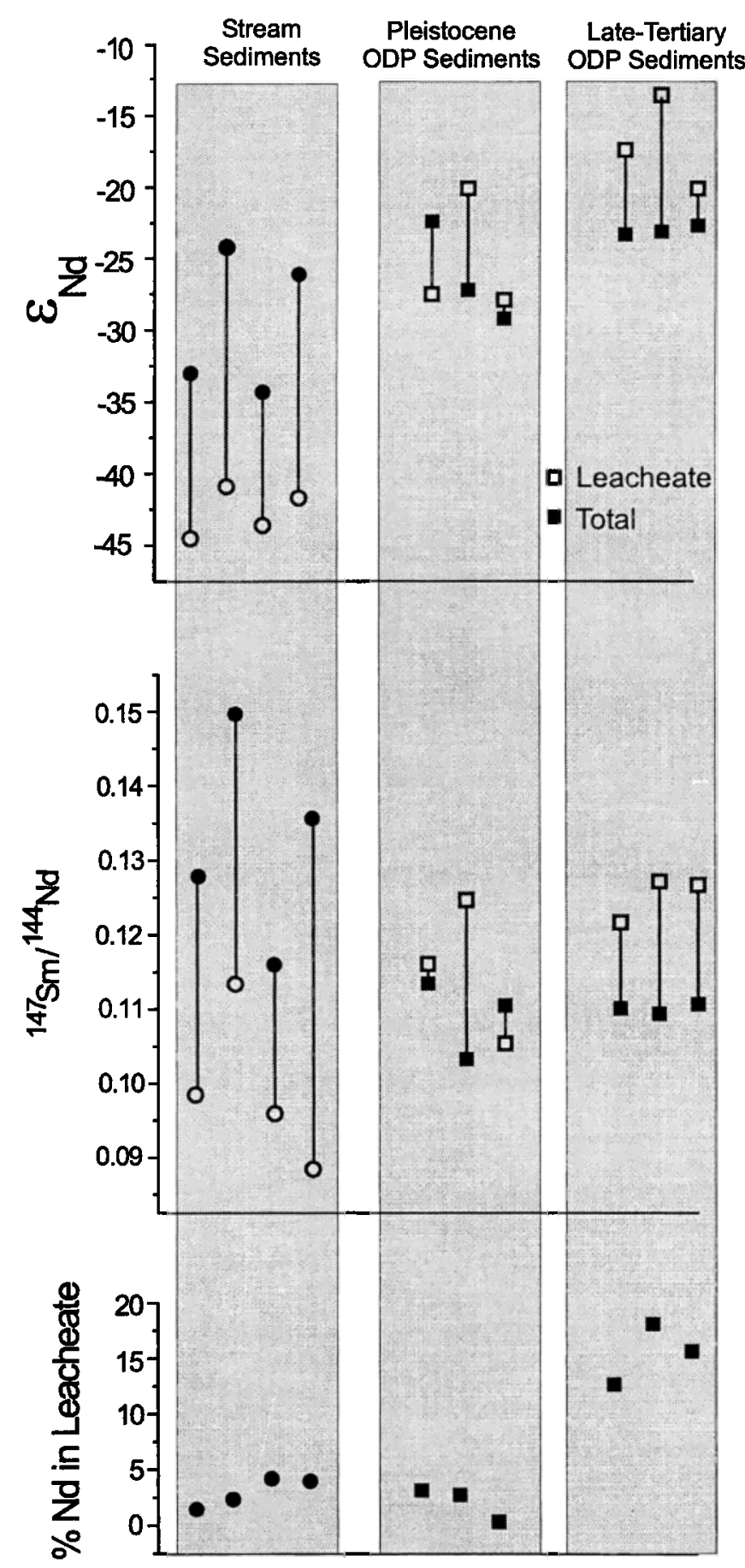

different deep-ocean $\tau(\mathrm{Pb}, \mathrm{Nd}, \mathrm{Hf})$; and they are absent in initial ${ }^{10} \mathrm{Be} /{ }^{9} \mathrm{Be}$ [von Blanckenburg and O'Nions, 1999].

The results of this study bear some potentially far-reaching implications for the use of intermediate- $\tau$ tracers in paleoceanography: First, whether changes in deep water circulation are recorded at all by radiogenic tracers depends on a sensitive balance between the residence time of the tracer and the water replenishment time of the basin. Second, isotopic compositions in seawater will not always represent their continental source in an unmodified composition. Third, the possibility exists that climate-driven changes in mechanical versus chemical erosion rate result in input of isotope tracers of compositions that vary on the timescales of climate cycles. Such signals can be dispersed basin-wide by rapid lateral advection [Igel and von Blanckenburg, 1999; von Blanckenburg and Igel, 1999] and might obscure isotope variations that result from changes in the thermohaline circulation. It will be important to distinguish between these two causes in paleoceanographic studies.

This conclusion does not invalidate the possible link between the closure of the Panama Gateway and an increase in Labrador Seawater convection. However, it does suggest that in this case, radiogenic isotope tracers would not necessarily record such a change in ocean circulation but are more likely to record changes in weathering associated with the onset of Northern Hemisphere glaciation and increased availability of glacial detritus. This is entirely compatible with observations from longer- $\tau$ ocean tracers [Hodell et al., 1990; Oxburgh, 1998; Peucker-Ehrenbrink and Blum, 1998].

Acknowledgments. The authors are grateful to the ODP program, in particular the crew and scientific staff of Leg 105, and also Stephen Moorbath for providing samples. Jan Kramers (Berne) is thanked for establishment of excellent new mass spectrometric facilities, Borgi Hebeisen is thanked for technical support, Ben Reynolds is thanked for a contribution to Figure 1, and Benedict De Silva is thanked for his grammatical view of oceanography. The thoughtful unofficial reviews by Martin Frank, Jan Kramers, and Thomas Stocker and constructive official reviews by Bernhard PeuckerEhrenbrink, Clark Johnson, and an anonymous reviewer improved earlier versions of this paper.

Figure 6. Nd isotope ratios, ${ }^{147} \mathrm{Sm} /{ }^{144} \mathrm{Nd}$, and percentage of $\mathrm{Nd}$ released during leacheate of dissolved bulk samples (solid symbols) and $0.05 \mathrm{M}$ $\mathrm{HCl}$ leacheates (open symbols) of river sediments (circles) and Ocean Drilling Program 645 sediments (squares). The leached fraction represents the Nd available for release into seawater. Analytical details are given in Table 2.

\section{References}

Abouchami, W., S.J.G. Galer, and A. Koschinsky, $\mathrm{Pb}$ and $\mathrm{Nd}$ isotopes NE Atlantic Fe-Mn crusts: Proxies for paleosources and paleocean circulation, Geochim. Cosmochim. Acta, 63, 14891505, 1999.

Albarède, F., A. Simonetti, J.D. Vervoort, J Blichert-Toft, and W. Abouchamie, A Hf-Nd isotopic correlation in ferromanganese nodules, Geophys. Res. Lett., 25, 3895-3898, 1998.

Andersson, P.S, R. Dahlqvist, J. Ingri and Ö. Gustafsson, The isotopic composition of $\mathrm{Nd}$ in a boreal river: A reflection of selective weath- ering and collordal transport, Geochim. Cosmochim. Acta, 65, 521-527, 2001.

Belshaw, N., P. Freedman, R. O'Nions, M. Frank, and $Y$. Guo, A new variable dispersion doublefocusing plasma mass spectrometer with performance illustrated for $\mathrm{Pb}$ isotopes, Int. $J$. Mass Spectrom., 181, 51-58, 1999

Burton, K.W., H.F. Ling and R.K. O'Nions, Closure of the Central American Isthmus and its effect on deep-water formation in the North Atlantic, Nature, 386, 382-385, 1997.

Burton, K., D. Lee, J. Christensen, A. Halliday, and J. Hein, Actual timing of neodymium isotopic variations recorded by Fe-Mn crusts in the western North Atlantic, Earth Planet. Sci. Lett., 171, 149-156, 1999.

Christensen, J.N., A.N. Halliday, L.V. Godfrey, J.R. Hein and D.K. Rea, Climate and ocean dynamics and the lead isotopic records in $\mathrm{Pa}$ cific ferromanganese crusts, Science, 277, 913918, 1997.

Cochran, J.K., et al., ${ }^{210} \mathrm{~Pb}$ scavenging in the North Atlantic and North Pacific Oceans, Earth Planet. Sci. Lett., 97, 332-352, 1990. 
Dickson, R.R., and J. Brown, The production of North Atlantic Deep Water: Sources, rates, and pathways, J. Geophys. Res., 99, 12,319-12,341. 1994.

Erel, Y., Y. Harlavan, and J D. Blum, Lead isotope systematics of granitoid weatherıng, Geochim Cosmochim. Acta, 58, 5299-5306, 1994

Frank, M., B.C. Reynolds, and R.K. ONions, Nd and $\mathrm{Pb}$ isotopes in Atlantic and Pacific water masses before and after closure of the Panama Gateway, Geology, 27, 1147-1150, 1999

Harlavan, Y., Y. Erel, and J.D. Blum, Systematic changes in lead isotopic composition with soi age in glacial granitic terrains, Geochim Cosmochim. Acta, 62, 33-46, 1998.

Haug, G.H., and R. Tiedemann, Effect of the formation of the Isthmus of Panama on Atlantic Ocean thermohaline circulation, Nature, 393. 673-676, 1998.

Heınze, C., and T.J Crowley, Sedimentary response to ocean gateway circulation changes, Paleoceanography, 12, 742-745, 1997.

Hodell, D., G. Mead, and P. Mueller, Variation in the strontium isotopic composition of seawater (8 Ma to present) - Implications for chemicalweathering rates and dissolved fluxes to the oceans, Chem. Geol., 80, 291-307, 1990

Igel, $H$. and $F$. von Blanckenburg, Lateral mixing and advection of reactive Isotope tracers in ocean basins: Numerical modelıng, Geochem. Geophys. Geosyst., I, Paper number 1999GC000003, [10,402 words, 15 figures, 3 tables, 2 movies]. December 13, 1999.

Kusakabe, M., T.L. Ku, J.R. Southon, and C.I. Measures, Beryllium isotopes in the ocean, Geochem. J., 24, 263-272, 1990.

Larsen, H.C., A.D. Saunders, P.D. Clıft, J. Beget, W. Wel, S. Spezzaferri, and ODP Leg 152 Sct entıfic Party, Seven million years of glaciation in Greenland, Science, 264, 952-955, 1994.

Lee, D.C, A.N. Halliday, J.R. Hein, K.W Burton, J.N. Christensen, and D. Gunther, Hafnium isotope stratigraphy of ferromanganese crusts. Science, 285, 1052-1054, 1999.

Mikolajewicz, U. and T.J. Crowley, Response of a coupled ocean/energy balance model to restncted flow through the central American isthmus, Paleoceanography, I2, 429-441, 1997.

Moorbath, S, M. Whitehouse, and B. Kamber, Extreme $\mathrm{Nd}$-isotope heterogeneity in the early
Archean - Fact or fiction? Case studies from northern Canada and west Greenland, Chem. Geol, 135, 213-231, 1997.

Öhlander, B , J. Ingrı, M. Land, and H. Schöberg, Change of Sm-Nd isotope composition during weathering of till, Geochim. Cosmochim. Acta 64, 813-820, 2000

O'Nions, R.K., M. Frank, F. von Blanckenburg and H.F. Ling, Secular variations of $\mathrm{Nd}$ and $\mathrm{Pb}$ isotopes in ferromanganese crusts from the Atlantic, Indian, and Pacific Oceans, Earth Planet. Sci. Lett., 155, 15-28, 1998.

Oxburgh, R. Vanations in the osmum isotope composition of sea water over the past 200,000 years, Earth Planet. Sci. Lett., IS9, 183-191, 1998.

Peucker-Ehrenbrink, B. and J.D. Blum, Re-Os systematıcs and weathering of Precambrian crustal rocks: Implications for the marine osmium isotope record, Geochim. Cosmochim. Acta, 62, 3193-3203, 1998.

Piepgras, D.J. and G J. Wasserburg, Rare earth element transport in the western North Atlantic inferred from $\mathrm{Nd}$ isotopic observations, Geochim. Cosmochim. Acta, 51, 1257-1271, 1987.

Piotrowski, A.M., et al., Changes in erosion and ocean circulation recorded in the Hf isotopic compositions of North Allantic and Indian Ocean ferromanganese crusts, Earth Planet. Sci. Lett., 181, 315-325, 2000

Reynolds, B.C., M. Frank, and R.K. O'Nions, Ndand $\mathrm{Pb}$-isotope time series from Atlantic ferromanganese crusts: Implications for changes in provenance and paleocirculation over the last $8 \mathrm{Myr}$, Earth Planet, Sci. Lett., 173, 381396, 1999.

Rutberg, R.L., S.R. Hemming, and S.L. Goldstein, Reduced North Atlantic Deep Water flux to the glacial Southern Ocean inferred from neodymium isotope ratios, Nature, 405, 935-938, 2000.

Schmitz, W.J., Jr., and M.S. McCartney, On the North Atlantic circulation, Rev. Geophys., 31, $29-49,1993$.

Silver, L.T., J.A. Woodhead, I.S. Willıams, and B.W. Chappell, Uranium in granites from the southwestern United States: Actinide parentdaughter systems, sites and mobilızation, $D E$ AC13-76G101664, Dep. of Energy, Washington DC., 1984
Srivastava, S., et al (Ed.), Proceedings of the Ocean Drilling Program, Scientific Results Leg I05, Ocean Drill. Progran, College Station, Tex., 1989.

Stanley, S M., New horizons for paleontology, with two examples: The rise and fall of the Cretaceous Supertethys and the cause of the modern ice age, J. Paleontol, 69, 999-1007, 1995

Stordal, M.C. and G.J. Wasserburg, Neodymıum isotopic study of Baffin Bay Water: Sources of REE from very old terranes, Earth Planet. Sci. Lett., 77, 259-272, 1986.

Vance, D, and K. Burton, Neodymium isotopes in planctonic foraminfera: a record of the response of continental weathering and ocean circulation rates to climate change, Earth Planet. Sci. Lett., 173, 365-379, 1999.

von Blanckenburg, F., Tracing past ocean circulation? Scrence, 286, 1862-1863, 1999.

von Blanckenburg, F., and H. Igel, Lateral mixing and advection of reactive isotope tracers in ocean basins: Observations and mechanisms, Earth Planet. Sci. Lett., 169, 113-128, 1999.

von Blanckenburg, F., and R.K. O'Nions, Response of beryllium and radiogenic isotope ratios in Northern Atlantic Deep Water to the onset of Northern Hemisphere glaciation, Earth Planet. Sci. Lett., 167, 175-182, 1999.

von Blanckenburg, F, R.K. O'Nions, and J.R. Hein, Distribution and sources of preanthropogenic lead isotopes in deep ocean water from Fe-Mn crusts, Geochim. Cosmochim. Acta, 60, 4957-4963, 1996.

Winter, B.L., C.M. Johnson, and D.L. Clark Strontıum, neodymium, and lead isotope variations of authigenıc and silicate sediment components from the Late Cenozorc Arctic Ocean: Implications for sediment provenance and the source of trace metals in seawater, Geochim. Cosmochim. Acta, 61, 4181-4200, 1997.

T.F. Nägler and F. von Blanckenburg, Isotopengeologie, Mineralogisch-Petrographisches Institut, Universität Bern, Erlachstrasse 9a. CH-3012 Bern, Switzerland. (fvb@mpi.unibe.ch)

(Reccived June 7, 2000; revised January 20, 200 I; accepted March 7, 2001.) 